\title{
Business Educators' Awareness and Adoption of Web 2.0 Technologies for Educational Instruction in Tertiary Institutions in South East Nigeria
}

\author{
Christiana Ngozi Ementa ${ }^{1} \&$ Chika Madu Ile ${ }^{1}$ \\ ${ }^{1}$ Department of Vocational Education, Nnamdi Azikiwe Univeristy, Awka, Nigeria \\ Correspondence: Christiana Ngozi Ementa, Department of Vocational Education, Nnamdi Azikiwe Univeristy, \\ Awka, Nigeria.
}

Received: January 15, 2016

Accepted: February 10, 2016

Online Published: March 15, 2016

doi:10.5430/irhe.v1n1p216

URL: http://dx.doi.org/10.5430/irhe.v1n1p216

\begin{abstract}
There is need for students of tertiary institutions to enjoy the enormous benefits of Web 2.0 technologies and tools which students use mainly for entertainment and recreation. This necessitated this investigation on the extent business educators in southeast Nigeria are aware of and adopt Web 2.0 technologies for educational instruction. Two research questions guided the study and four null hypotheses were tested at 0.05 level of significance. The survey design was adopted for the study. Population of the study was 144 business educators and there was no sampling. The research instrument was a structured 5-point scale questionnaire validated by three experts in ICT and measurement and evaluation. The reliability of the instrument was established using Split half method. Mean was used to answer the research questions while t-test was used to test the null hypotheses. The study found that the respondents were highly aware of Web 2.0 technologies and adopt Web 2.0 technologies for class interaction to a very low extent. The study also found that age was a factor in business educators' rating of awareness and adoption of Web 2.0 technologies for educational instruction while sex, years of experience in teaching and type of institution did not affect their response. It was recommended, among others, that management of tertiary institutions should train business educators on the usage of Web 2.0 for educational activities.
\end{abstract}

Keywords: business educators, Web 2.0, educational instruction

\section{Introduction}

In education, instruction is the facilitation of learning towards achieving identified learning goals. Oladosu (2009) viewed instruction as the process whereby the environment of the learner or an individual is deliberately managed to enable the learner learn to exhibit certain behaviours under specified condition(s) or as a response to a specified situation. Educational instruction could be provided through traditional (teacher centered) approach or student-centered approach. Traditional instruction involves the use of conventional means which is largely face-to-face interaction to convey instructional materials through the use of classrooms and study centers. The traditional instruction delivery requires the physical presence of students to take place (Alaneme, Olayiwola \& Reju, 2008). Riordan (1993) noted that traditional instruction delivery in higher education involves lecturing and presentation of information, and teaching taking place mainly within the classroom. Redmann and Kotrlik (2008) described the traditional learner as one who would listen to class lectures, take notes and prepare for written tests. On the other hand, student centered approach is an instructional delivery approach where the learner is an active participant in the learning process, who monitor their learning to develop strategies for learning, and work in collaboration with others. Di Napoli (2004) viewed student centered approach as an active dynamic process where the learner constructs knowledge by interacting with his/her teachers and data gathered through different sources, with the aim of solving a problem or an assigned task. The Geological Society of America (2015) described student centered instructional approach as one which provides opportunities for students to engage in self-learning, for instance is an online search for relevant information using the instructor as a guide to access needed information. Jones (2007) noted that in student centered class, the teacher guides the students, manages their activities and direct their learning; the teacher's role is that of a facilitator rather than an instructor.

In most tertiary institutions in Nigeria, instructional delivery of business education programmes is characterized by face-to-face method of teaching and learning. Mamman and Nwabufo (2014) affirmed that instructional provision in business education programme is carried out using conventional methods in which students are told what to learn, 
where to learn as well as when and how to learn. This traditional method of providing educational instruction cannot effectively prepare digital age learners for tomorrow's world of works. Rapp (2005) stated that teacher-centered instruction is no longer a viable learning option for today's digital age learners. Furthermore, Polka (2001) noted the need for institutions to migrate from using a teacher-centered model of instruction to a student-centered model of instruction so as to facilitate effective instruction.

The advent of the internet and technological devices has presented challenges to teacher centered mode of instruction delivery. Barnett, Keating, Harwook and Saam (2004) asserted that internet technologies such as e-mail, course websites and news groups have added value to traditional classroom knowledge delivery and have impacted course delivery and design in many colleges and universities. Yuen, Yaoyuneyong and Yuen (2011) asserted that the advent of Web 2.0 as a learning technology has transformed the internet into a global network of interconnected learning communities and have changed the ways teachers and students interact.

Web 2.0 is an internet-enabled web application which allows people to collaborate, get actively involved in creating content, generating knowledge and sharing information online. O'Reilly (2007) defined Web 2.0 as a web platform and web applications that run on the platform that provides users control over their own content and facilitate collaboration between individuals and groups. There are numerous Web 2.0 tools/applications with potentials in education. The tools include but are not restricted to:

Blogs: Blog is the short form of weblog. The phrase 'weblog' was created by Jorn Barger in 1997 resulting from the amalgamation of two words 'web' and 'log' (Kaiser, Muller-Seitz, Lopes \& Pina e Cunha, 2007). Blogs are websites maintained by an individual with regular commentary entries, event descriptions, or other material such as graphics or video. Baker (2003) noted that instructors can use blogs for networking and personal knowledge sharing, instructional tips for students, course announcements and readings, annotated links for reading or reference and for experience and content sharing.

Wikis: The term 'Wiki' originated from Hawaii which means fast. A wiki is a collection of webpages designed to enable anyone with access to contribute or modify content, using a simplified markup language, and is often used to create collaborative websites (Enonbun, 2010). Noting the important feature of Wiki, Baxter, Connolly, Stansfield, Tsvetkova, and Stoimenova (2011) explained that wiki is useful for maintaining a revision history of co-authored pages which allow knowledge to be shared among students over a sustained period. Alexander (2006) noted that wiki support individualized learning, allow for more socially defined search structures and promote collaboration through group editing and peer review.

Social networks: Social networking sites are websites that permit individuals to create and become members of a virtual community. Stern (2008) described social networks as websites which provide a virtual community for people interested in a particular subject, where members create their own online profile pages with biological data, pictures, likes, dislikes and any other information they choose to post. Some social networking sites include: Facebook, LinkedIn, MySpace, Twitter, Friendster, WhatsApp, Badoo, Flickr and so on.

Podcasts: Podcasts are digital media files (usually audio or video) available for download from the internet; the file can then be played on a personal computer or mobile device at the users' convenience. Harris and Lea (2009) asserted that podcasts can be used in online courses as a method of delivering content to students, supplementing lectures or class presentations, and allowing educators to rapidly and timely address students' needs and concerns as they arise.

Virtual Worlds: Virtual worlds, also referred to as virtual learning environment are computer simulated environment where real people are characterized by avatars, which enables users to interact with others without environmental confines. Typical instance is SecondLife.

Online Forum: These are called online bulletin boards or online discussion boards. Online forum is a many-to many discussion space where users/participants can communicate, discuss and share ideas on issues of interest. Ward (2012) defined online discussion board as a part of an online site where instructors and students can exchange questions and answers. An example of online discussion board is Blackboard.

Highlighting the benefits of Web 2.0 technologies usage in education, Baxter, Dimitrova et al (2011) noted that Web 2.0 gives students greater degree of independence on how and when they learn and teachers are viewed as supporters in the use of Web 2.0 technologies who coordinate learning and provide feedback to students in their engagement with Web 2.0 tools. Web 2.0 technologies provide a reach, shared virtual learning, where interactions are taking place not only between learners and technology but among learners who share a mutual aim, and the interactions facilitated by an instructor (Vrettaros, Tagoulis, Giannopoulou \& Drigas, 2009). 
The purpose of teaching is to impart learning and promote understanding. Business educator as a teacher is expected to be abreast with the use of technology to effectively cater for the learning needs of today's learner who are referred to as 'digital natives' (young learners who access and process information quickly, multitask more easily, prefer graphics to text, random to sequential access, thrive on instant gratification and rewards, and prefer games to serious work - (Prensky, 2001). Business educators are teachers who impart knowledge and skills needed to prepare individuals for the workplace and for self-dependence. A business educator in the context of this study is same as teacher or lecturer in business education programme. Business educators in tertiary institutions need to monitor changes in technologies and seek ways to use technological tools to support and strengthen provision of pedagogical instruction. Bates (2011) noted how critical it is for educational institutions to have processes in place that encourage dynamic change, innovative uses of technology, monitoring and evaluation of what works and what does not. Ramsden (2003) further noted that active participation and social aspects of learning serve as the framework for the design of learning experiences which will ensure that students develop the understanding and abilities they need in order to respond and shape the world they live in.

The researchers are worried that business education students seem not to harness the enormous potentials of Web 2.0 technologies as they are constantly busy with their laptops and mobile phones taking pictures, chatting, updating profiles even when classes/lectures are on. This ugly situation could be traced to whether or not business educators are aware of Web 2.0 and whether they adopt it in the instructional process. Ezenwafor (2012) affirmed that the extent students are exposed to the use of technologies depends on lecturers' use of technologies to engage them in practice sessions. Although studies have been conducted on the use of Web 2.0 in education in Nigeria (Ajise \& Fagbola, 2013; Mamman \& Nwabufo, 2014), none to the best of the researchers' knowledge sought business educators' opinion on awareness and adoption of Web 2.0 for specific educational instruction. This study therefore sought to ascertain business educators' awareness and adoption of Web 2.0 for educational instruction. Specifically, the study sought to find out business educators awareness of Web 2.0 technologies and adoption of Web 2.0 for class interaction.

\section{Research Questions}

The following research questions guided the study

1) To what extent are business educators in tertiary institutions in south east Nigeria aware of Web 2.0 technologies?

2) To what extent do business educators in tertiary institutions in south east Nigeria adopt Web 2.0 for class interaction?

\subsection{Hypotheses}

The following null hypotheses were tested at 0.05 level of significance

1) Male and female business educators in tertiary institutions in south east Nigeria do not differ significantly in their mean rating of adoption of Web 2.0 technologies for class interaction.

2) Business educators aged below 45 years and business educators aged 45 years and above in tertiary institutions in south east Nigeria do not differ significantly in their mean rating of adoption of Web 2.0 technologies for class interaction.

3) Experienced and less experienced business educators in tertiary institutions in south east Nigeria do not differ significantly in their mean rating of adoption of Web 2.0 technologies for class interaction.

4) Business educators in universities and colleges of education in south east Nigeria do not differ significantly in their mean rating of adoption of Web 2.0 technologies for class interaction.

\section{Theoretical Underpinning}

Application and use of Web 2.0 for educational instruction could be understood by reviewing certain theories. For example, social constructivism theory by Vygotsky in 1962. Vygotsky's theory stressed the fundamental role of social interaction as a dimension of learning. Two main principles of Vygotsky's work are: More Knowledgeable Other - which refers to someone who has a higher ability level than the learner with respect to a particular task, process or concept; and Zone of Proximal Development - which is the distance between the actual developmental level as determined by independent problem solving and the level of potential development as determined through problem solving under adult guidance or in collaboration with more capable peer (Vygotsky, 1978). The implication of Vygotsky social constructivism theory to the study is that Web 2.0 is ideal for mediating social interactions and 
collaboration, as learning is an active process which requires collaboration between teachers and students in order to facilitate meaning construction in students.

Another instance is the theory of distributed cognition by Hutchins in 1980. The theory stems from the work of Vygotsky. This theory is based on the idea that knowledge is distributed across many individuals and devices, and each person or device involved holds certain and unique information that only when brought together helps create complete understanding (Hutchins, 1995). Distributed cognition theory has been greatly influential in understanding how humans work with technology. Specifically, it has been widely applied in the field of human-computer interaction with particular emphasis on computer supported collaborative learning. This theory relates to the study as Web 2.0 is an application that is highly interactive and serves as an ideal tool that enables meaningful collaboration between individuals and the computer. Examples of its application include collaborative tagging on the internet offered on websites like YouTube, writing and editing application such as GoogleDoc which allow multiple people to edit a shared document at the same time.

\section{Method}

The design adopted for the study was survey research design. Osuala (2004) recommended that survey research design is most appropriate for studies which center on individuals and their opinions, beliefs, motivation and behaviour. The study was conducted in five South East States of Nigeria, namely; Abia, Anambra, Ebonyi, Enugu and Imo States. The population of the study comprised 144 business educators in universities and colleges of education. The entire population was studied because the number was not too large to warrant sampling. A structured questionnaire with 36 items altogether in two clusters (B1 and B2) was used for data collection. Out of the 144 copies administered, one hundred and twenty- five copies were duly returned and used for data analysis. Data collected were analyzed using mean and standard deviation for the research questions and t-test for the hypotheses. For the research questions, real limits of numbers of 4.50- 5.00 (Very High Extent), 3.50 - 4.49 (High Extent), 2.50 3.49 (Moderate Extent), 1.50 - 2.49 (Low extent), 0.50-1.49 (Very Low Extent) was used. Standard deviation value close to 0 was an indication of homogeneity in agreement among the respondents while standard deviation value far from 0 is an indication that the agreement among the respondents was loose, wide apart or heterogeneous. In testing the hypotheses, the decision rule was to accept the null hypothesis where the p-value is greater than 0.05 and reject the null hypothesis where p-value is less than or equal to 0.05 .

\section{Results}

The results of the study are presented below;

\section{Research Question 1}

To what extent are business educators in tertiary institutions in south east Nigeria aware of Web 2.0 technologies?

Table 1. Respondents' mean ratings and standard deviation of awareness of Web 2.0 technologies

\begin{tabular}{|c|c|c|c|c|}
\hline $\mathbf{S} / \mathbf{N}$ & Web 2.0 technologies & Mean & SD & Remarks \\
\hline 1 & Blogs & 3.38 & 0.03 & Moderate Extent \\
\hline 2 & Wikis & 4.09 & 0.43 & High Extent \\
\hline 3 & Facebook & 4.84 & 0.54 & Very High Extent \\
\hline 4 & Twitter & 4.27 & 0.14 & High Extent \\
\hline 5 & Bebo & 3.44 & 0.55 & Moderate Extent \\
\hline 6 & LinkedIn & 3.93 & 0.24 & High Extent \\
\hline 7 & Friendster & 3.83 & 0.76 & High Extent \\
\hline 8 & WhatsApp & 4.13 & 0.54 & High Extent \\
\hline 9 & MySpace & 3.83 & 0.14 & High Extent \\
\hline 10 & YouTube & 3.49 & 0.55 & Moderate Extent \\
\hline 11 & Flickr & 4.27 & 0.24 & High Extent \\
\hline 12 & $2 \mathrm{go}$ & 3.44 & 0.76 & Moderate Extent \\
\hline 13 & Badoo & 3.88 & 0.54 & Moderate Extent \\
\hline 14 & Virtual Worlds/Virtual Learning Environment & 3.83 & 0.43 & Moderate Extent \\
\hline 15 & Podcast & 3.12 & 0.54 & Moderate Extent \\
\hline 16 & Online discussion forum & 4.39 & 0.14 & High Extent \\
\hline
\end{tabular}


The data in Table 1 reveal the respondents' rating of awareness of Web 2.0 technologies. The Table shows that seven items out of the sixteen items had mean values ranging from 3.12 to 3.49 which fell within the range regarded as 'moderate extent'. Eight items had mean values ranging from 3.83 to 4.39 which fell within the range regarded as 'high extent' while one item had a mean value of 4.84 which fell within the range regarded as 'very high extent'. However, with the mean of means of 3.89 which fell within the high extent range, it showed that the respondents were aware of Web 2.0 to a high extent. Additionally, Friendster and $2 \mathrm{go} \mathrm{had}$ a standard deviation value of 0.76 each. This showed how wide apart the opinions of the respondents were in rating the web tools.

\section{Research Question 2}

To what extent are business educators in tertiary institutions in south east Nigeria adopt Web 2.0 for class interaction?

Table 2. Respondents' mean rating and standard deviation on adoption of Web 2.0 technologies for class interaction

\begin{tabular}{|c|c|c|c|c|}
\hline $\mathbf{S} / \mathbf{N}$ & Applications of Web 2.0 for class interaction & Mean & SD & Remarks \\
\hline 1 & Use blogs to read contents from students. & 1.25 & 0.34 & Very Low Extent \\
\hline 2 & Use blogs to explain concepts for students. & 1.31 & 0.51 & Very Low Extent \\
\hline 3 & Use blogs to post study guides to students. & 2.24 & 0.44 & Low Extent \\
\hline 4 & Use blogs to group students for collaborative peer learning. & 2.18 & 0.32 & Low Extent \\
\hline 5 & Use wikis to share digital files with students. & 1.32 & 0.24 & Very Low Extent \\
\hline 6 & Use wikis to modify contents in collaboration with students. & 1.18 & 0.18 & Very Low Extent \\
\hline 7 & Use wikis to assign portfolio pages for students to display work. & 1.26 & 0.45 & Very Low Extent \\
\hline 8 & $\begin{array}{l}\text { Use social networks group page to send announcements about class to } \\
\text { students. }\end{array}$ & 1.19 & 0.34 & Very Low Extent \\
\hline 9 & $\begin{array}{l}\text { Use social networks group page to schedule events that related to } \\
\text { lesson for students. }\end{array}$ & 2.08 & 0.64 & Low Extent \\
\hline 10 & Use social networks group page to post notes for students to read. & 1.53 & 0.52 & Low Extent \\
\hline 11 & Use podcasts to air audio lecture recording for students to download. & 1.23 & 0.41 & Very Low Extent \\
\hline 12 & $\begin{array}{l}\text { Use podcasts to publish video demonstrations for students to } \\
\text { download. }\end{array}$ & 1.27 & 0.34 & Very Low Extent \\
\hline 13 & $\begin{array}{l}\text { Use virtual worlds/Virtual Learning Environment to simulate lessons } \\
\text { for students with special needs. }\end{array}$ & 1.08 & 0.19 & Very Low Extent \\
\hline 14 & Use virtual worlds to create thematic units to explain complex ideas. & 1.01 & 0.13 & Very Low Extent \\
\hline $\begin{array}{l}15 \\
16\end{array}$ & $\begin{array}{l}\text { Use online forum to clarify rules/expectations to students. } \\
\text { Use online forum for lesson discussion with students. }\end{array}$ & $\begin{array}{l}1.01 \\
1.24\end{array}$ & $\begin{array}{l}0.15 \\
0.25\end{array}$ & Very Low Extent \\
\hline & & 1.23 & 0.32 & Very Low Extent \\
\hline
\end{tabular}

The data in Table 2 show that four out of the sixteen items on adoption of Web 2.0 for class interaction had mean values of 2.08 to 2.24 which fell within the range regarded as low extent while the remaining twelve items had mean values ranging from 1.01 to 1.32 which fell within the range regarded as very low extent. Nevertheless, with the mean of means at 1.41 which fell within the range regarded as very low extent show that the respondents adopt Web 2.0 for class interaction to a very low extent. The standard deviation which ranged from 0.13 to 0.64 shows how wide apart the respondents opinion is in rating the items.

\section{Hypothesis 1:}

Male and female business educators in tertiary institutions in south east Nigeria do not differ in their mean ratings of adoption of Web 2.0 technologies for class interaction. 
Table 3. t-test of difference between the mean rating of male and female business educators on adoption of Web 2.0 technologies for class interaction

\begin{tabular}{lccccccc}
\hline Gender & $\mathbf{N}$ & $\overline{\boldsymbol{X}}$ & $\mathbf{S D}$ & $\mathbf{D F}$ & t-value & p-value & Remarks \\
\hline Male & 14 & 2.19 & 0.65 & & & & \\
& & & & 20 & 1.24 & 0.24 & Not Significant \\
Female & 14 & 1.91 & 0.44 & & & & \\
\hline
\end{tabular}

The data in Table 3 reveal the t-test of difference between the mean ratings of male and female business educators on the adoption of Web 2.0 technologies for class interaction. The p-value of the test is 0.24 which is greater than 0.05 . This provides evidence that the null hypothesis of no significant difference is not rejected. This means that there is no significant difference between the mean ratings of male and female business educators regarding adoption of Web 2.0 for class interaction.

\section{Hypothesis 2}

Business educators aged below 45 years and business educators aged 45 years and above in tertiary institutions in south east Nigeria do not differ on their mean ratings of adoption of Web 2.0 technologies for class interaction.

Table 4. t-test of difference between mean ratings of business educators below 45 years and business educators 45 years \& above on adoption of Web 2.0 technologies for class interaction

\begin{tabular}{lccccccc}
\hline Age & $\mathbf{N}$ & $\overline{\boldsymbol{X}}$ & SD & DF & t-value & p-value & Remarks \\
\hline Below 45 years & 14 & 2.01 & 0.35 & & & & \\
& & & & 20 & 5.06 & 0.00 & Significant \\
45 years \& above & 14 & 1.33 & 0.34 & & & \\
\hline
\end{tabular}

The data in Table 4 show t-test of difference between mean ratings of business educators below 45 years of age and business educators aged 45 years and above on adoption of Web 2.0 technologies for class interaction. The p-value of the test is 0.00 which is less than 0.05 . This provides evidence that the null hypothesis of no significant difference is rejected. This means that there is a significant difference between the mean ratings of business educators below 45 years of age and business educators aged 45 years and above on adoption of Web 2.0 for class interaction.

\section{Hypothesis 3}

Experienced and less experienced business educators in tertiary institutions in south east Nigeria do not differ in their mean rating of adoption of Web 2.0 technologies for class interaction.

Table 5. t-test of difference between the mean rating of experienced and less experienced business educators on adoption of Web 2.0 technologies for class interaction

\begin{tabular}{lccccccc}
\hline $\begin{array}{l}\text { Years of experience } \\
\text { in teaching }\end{array}$ & $\mathbf{N}$ & $\overline{\boldsymbol{X}}$ & $\mathbf{S D}$ & $\mathbf{D F}$ & t-value & p-value & Remarks \\
\hline Experienced & 14 & 1.98 & 0.50 & & & & Not Significant \\
Less Experienced & 14 & 2.05 & 0.60 & 20 & 0.41 & 0.69 & \\
\hline
\end{tabular}

The data in Table 5 show t-test of difference between mean rating of experienced and less experienced business educators on adoption of Web 2.0 technologies for class interaction. The p-value of the test is 0.69 which is greater than 0.05 . This provides evidence that the null hypothesis of no significant difference is not rejected. This means that there is no significant difference between the mean ratings of experienced and less experienced business educators regarding adoption of Web 2.0 technologies for class interaction.

\section{Hypothesis 4}

Business educators in universities and colleges of education in south east Nigeria do not differ in their mean rating of adoption of Web 2.0 technologies for class interaction. 
Table 6. t-test of difference between the mean rating of business educators in universities and colleges of education on adoption of Web 2.0 technologies for class interaction

\begin{tabular}{|c|c|c|c|c|c|c|c|}
\hline Type of institution & $\mathbf{N}$ & $\bar{X}$ & SD & DF & t-value & p-value & Remarks \\
\hline \multirow[t]{2}{*}{ University } & 14 & 1.99 & 0.69 & & & & \\
\hline & & & & 20 & 0.77 & 0.45 & Not Significant \\
\hline College of Education & 14 & 2.15 & 0.56 & & & & \\
\hline
\end{tabular}

The data in Table 6 reveal the t-test of difference between the mean rating of business educators in universities and colleges of education on adoption of Web 2.0 technologies for class interaction. The p-value of the test is 0.45 which is greater than 0.05 . This provides evidence that the null hypothesis of no significant difference is not rejected. This means that there is no significant difference between the mean ratings of business educators in universities and colleges of education regarding adoption of Web 2.0 technologies for class interaction.

\section{Discussion}

Findings of the study regarding the extent business educators are aware of Web 2.0 technologies, showed that business educators in tertiary institutions south east Nigeria were aware of Web 2.0 to a high extent. This finding is in disparity with the findings of Mtega, Dulle, Malekani and Chailla (2014) who reported that teaching staff in Tanzania are not aware of Web 2.0 tools. This finding is however in agreement with the findings of Ajise and Fagbola (2013) who reported a high level of awareness of Web 2.0 by lecturers in tertiary institutions in Nigeria. Web 2.0 technologies which business educators are aware of most include Facebook, Wikis, Twitter, WhatsApp and online discussion forum. Business educators' awareness of these technologies could be as a result of the presence of Web 2.0 tools in smartphones, tablets, netbooks which people use for day-to-day communication and interaction.

With regards to the adoption of Web 2.0 technologies for class interaction, sixteen activities using Web 2.0 for class interaction were listed. The adoption of four activities out of the sixteen activities was rated low extent while the adoption of the remaining twelve activities was rated very low extent by the respondents. On the other hand, a mean of means of 1.41, which fell within the range of very low extent, indicated that respondents adopted Web 2.0 technologies for class interaction to a very low extent. This finding is in line with the findings of Olasina (2011) who reported a low adoption of Web 2.0 in teaching and learning processes. Light and Polin (2010) emphasized that the use of Web 2.0 enhanced interaction and communication among students, between students and teachers and among educators. In addition, Weller (2013) noted that teachers need to be able to interact and deliver lessons in or out of class using Web 2.0 technologies as it is not only beneficial for students' class tasks, but a fun to use. Echeng, Usoro and Majewski (2013) recommended that a better learner centered approach can be achieved when education and training institutions adopt 21 st-century technologies like Web 2.0 to improve learner engagement.

With reference to the first hypothesis, the findings revealed that male and female business educators did not differ significantly in their mean ratings of adoption of Web 2.0 for class interaction. This means that gender is not a factor in the respondents' adoption of Web 2.0 for class interaction. This finding is in line with the findings of Quadri (2014) who found that age does not have significant effect on teachers' use of Web 2.0 to teach. This finding, however, contradicts the findings of Collins and Hide (2010) who reported that male teachers adopt and use Web 2.0 more than female teachers because male have positive attitude towards the use of Web 2.0 tools and provide alternative ways to form networks.

With reference to the second hypothesis, the finding revealed a significant difference in the mean rating of the respondents. The finding further revealed that business educators aged below 45 years adopt Web 2.0 technologies for class interaction more than business educators aged 45 years and above. This finding is in consonance with the report of Procter, Williams, Stewart, Poschen, Snee, Voss, and Asgari-Targhi (2010) who reported that young people adopt and use Web 2.0 technologies in teaching easily than adults because of their eagerness to learn and use new technologies.

With regards to the third hypothesis, the finding showed no significant difference in the mean rating of the respondents. This finding is in line with the discovery of Yeun, Yaoyuneyong and Yeun (2011) who stated that years of experience in teaching does not affect teachers adoption of Web 2.0 in teaching and learning.

With reference to the fourth hypothesis, the finding indicated a no significant difference in the rating of the respondents. The finding is in disagreement with the findings of Meyer and Xu (2009) who found that research faculties use Web 2.0 tools in teaching and learning than college faculties. This disparity is because of the nature of the institution where the former is concerned with research and teaching while the latter is concerned basically with teaching. The finding of the fourth hypothesis may be attributed to the fact that lecturers in universities and colleges of education akin to traditional mode of instruction presentation. 


\section{Conclusion and Implications of the Study}

It is concluded from the findings that awareness of Web 2.0 technologies has not resulted in its adoption in the instructional process. Business educators' degree of awareness of these web tools is not matched with their utilization for class instruction. This implies that instructional delivery in tertiary institutions in south east Nigeria is not structured around learners' interest as to allow the learners to seek appropriate resources and to support the development of learning outcomes of contemporary learners. It was also concluded that young business educators use Web 2.0 technologies for instructional purposes more than older business educators. This could be because the older business educators are digital immigrants who were not educated with these web tools. The implication is that it would be necessary to sensitize and train older business educators on the use of Web 2.0 technologies for educational instruction.

\section{Recommendations}

In the light of the findings and conclusion of the study, the researchers proffer the following recommendations:

1) Management of tertiary institutions in south east Nigeria should provide electronic learning facilities such as computer studios with high-speed internet access facilities to enable lecturers and students have adequate access to the web.

2) Business educators of all age brackets should keep abreast of emerging web technologies and adopt same for instruction to effectively cater for the learning needs of tomorrow's learners. This is to ensure that all business educators are attuned with the current methods and application of web technologies in education.

3) Tertiary institution management and professional bodies such as the Association of Business Educators of Nigeria (ABEN) should organize workshops, symposia and seminars to train business educators on the use of Web 2.0 technologies. This would strengthen business educators' instructional delivery capabilities.

\section{References}

Ajise, B., \& Fagbola, O. O. (2013). Awareness and usage of Web 2.0 tools among lecturers in Nigeria universities: Implications for teaching and learning in schools. Nigerian School Library Journal, 12, 93-107.

Alaneme, G.C, Olayiwola, P.O., \& Reju, C.O. (2008). Combining traditional learning and the e-learning methods in higher distance education: Assessing learners' preference. Retrieved from http://www.icdle.org/icdle10.toc

Barnett, M., Keating, T., Harwook, W., \& Saam, J. (2004). Using emerging technologies to help bridge the gap between university theory and classroom practice: challenges and successes. School Sciences and Mathematics, 106(2), 299-314.

Bates, T. (2011). Understanding Web 2.0 and its implication for e-learning. In M. J. W, Lee \& C. McLoughlin (Eds.), Web 2.0 based E-learning: Applying school informatics for tertiary teaching. New York: Information Science Reference.

Baxter, G. J., Connolly, T. M., Stansfield, M. H., Gould, C., Tsvetkova, N., Kusheva, R., ... Dimitrova, N. (2011). Understanding the pedagogy Web 2.0 supports: the presentation of Web 2.0 pedagogical model. Retrieved from www.web2Derc.eu/Web2.0pedagogical_model_salamanca_final V2.pdf

Baxter, G. J., Connolly, T. M., Stansfield, M. H., Tsvetkova, N., \& Stoimenova, B. (2011). Introducing Web 2.0 in Education: A Structured Approach Adopting a Web 2.0 Implementation Framework. Next Generation Web Services Practices (NWeSP), 499-504.

Collins, E., \& Hide, B. (2010). Use and relevance of Web 2.0 resources for researchers. Retrieved from http://elpub.scix.net/data/works/att/119_elpub2010.content.pdf

Di Napoli, R. (2004). What is student centered learning. Educational Initiative Centre (EIC) Guide. Retrieved from http://www.westminster.ac.uk/

Echeng, R., Usoro, A., \& Majewski, G. (2013). Acceptance of Web 2.0 in learning in higher education. A case study, Nigeria. International Journal of Advanced Computer Science and Applications, 4(10), 146-151. http://dx.doi.org/10.14569/IJACSA.2013.041022

Enonbun, O. (2010). Constructivism and Web 2.0 in the emerging learning Era: A global perspective. Journal of Strategic Innovation and Sustainability, 6(4), 17-27.

Ezenwafor, J. I. (2012). Adequacy of exposure to information and communication technology by graduating business education students of tertiary institutions in Anambra state. Business Education Journal, 8(2), 45- 60.

Geological Society of America. (2015). Student-Instructor classroom interaction. Retrieved from http://serc.carleton.edu?NAGTworkshops/certop/omp-sti.html 
Harris, A. L., \& Lea, A. (2009). Web 2.0 and virtual world technologies: A growing impact in IS education. Journal of Information Systems Education, 20(2), 137-144.

Hutchins, E. (1995). Cognition in the Wild. Cambridge, MA: MIT Press

Jones, L. (2007). The student centered classroom. New York: Cambridge University Press.

Kaiser, S., Muller-Seitz, M., Lopes, P., \& Pina e Cunha, M. (2007). Weblog- technology as a trigger to elicit passion for knowledge. Organization, 14(3), 391-412 http://dx.doi.org/10.1177/1350508407076151

Mamman, J. S., \& Nwabufo, B. N. (2014). Barriers to integration of Web 2.0 technologies in teaching/learning of business education courses in Nigerian universities. Business Education Journal, 2(1), 28 - 38.

Meyer, K. A., \& Xu, Y. J. (2009). A causal model of factors influencing faculty use of technology. Journal of Asynchronous Learning Networks, 13(2), 57-70.

Mtega, W. P., Dulle, F. W., Malekani, A. W., \& Chailla, A. W. (2014). Awareness and use of Web 2.0 technologies in sharing of agricultural knowledge in Tanzania. Knowledge Management \& E-Learning, 2(6), 188-202.

O'Reilly, T. (2007). What is Web 2.0: Design patterns and business models for the next generation of software? Communications and Strategies, 65, 17-37.

Oladosu, A. G. A. S. (2009). Concepts in education. In I. O. Abimbola and A. O. Aboladw (Eds.), Fundamental Principles and Practice of Instruction. Ilorin: University of Ilorin.

Olasina, G. (2011). The use of Web 2.0 tools and social networking sites by librarians, information professionals, and other professionals in workplaces in Nigeria. Pacific Northwest Library Association (PNLA) Quarterly, $75(3), 72-33$.

Osuala, E. C. (2004). Foundations of vocational education. Enugu: Cheston Publishers.

Polka, W. (2001). Facilitating the transition from teacher centered to student centered instruction at the university level via constructivist principles and customized learning plans. Educational Planning, 13(3), 55-61.

Prensky, M. (2001). Digital natives, digital immigrants. Horizon, 9(5), 1-6. http://dx.doi.org/10.1108/10748120110424816

Procter, R., Williams, R., Stewart, J., Poschen, M., Snee, H., Voss, A., \& Asgari-Targhi, M. (2010). Adoption and use of Web 2.0 in scholarly communications. Philosophical Transactions of the Royal Society A, 368(1926), 4039-4056.

Quadri, L. K. (2014). Teachers perception and attitudes toward the implementation of Web 2.0 tools in secondary schools. Unpublished dissertation of Walden University.

Ramsden, P. (2003). Learning to Teach in Higher Education. New York: Routledge Falmer.

Rapp, W. (2005). Inquiry-based environments for the inclusion of students with exceptional learning needs. Remedial and Special Education, 26, 297-310.

Redmann, D., \& Kotrlik, J. (2008). A trend study: Technology adoption in the teaching learning process by secondary school business teachers- 2002-2007. The Delta PI Epsilon Journal, 1(2), 77-89.

Riordan, T. (1993). Beyond the Debate: The Nature of Teaching. Milwaukee: Alverno College Institute.

Stern, J. (2008). Introduction to Web 2.0 technologies. Retrieved from http://www.wlac.edu/.../Web_2.0\%20v.02.pdf

Vrettaros, J., Tagoulis, A., Giannopoulou, N., \& Drigas, A. (2009). An empirical study on the use of Web 2.0 by Greek adult instructors in educational procedures. World Summit on Knowledge System (WSKS), 49, 164-170. http://dx.doi.org/10.1007/978-3-642-04757-2_18

Vygotsky, L. S. (1962). Thought and Language. Cambridge, MA: MIT Press. http://dx.doi.org/10.1037/11193-000

Vygoysky, L. S. (1978). Mind in Society: The Development of Higher Psychological Process. Cambridge, MA: MIT Press.

Ward, D. (2012). Socratic Method and Online Teaching. Retrieved from http://codl.ku.edu/

Weller, A. (2013). The use of web 2.0 technology for pre-service teacher learning in science education. Research in Teacher Education, 3(2), 40-46.

Yuen, S. C. Y., Yaoyuneyong, G., \& Yuen, P. K. (2011). Perceptions, interests and use: Teachers and Web 2.0 tools in education. International Journal of Technology in Teaching and Learning, 7(2), 109-123. 